\title{
Tropical pancreatic diabetes in South India: heterogeneity in clinical and biochemical profile
}

\author{
V. Mohan, R. Mohan, L.Susheela, C. Snehalatha, G. Bharani, V. K. Mahajan, A. Ramachandran, \\ M. Viswanathan and E. M. Kohner ${ }^{1}$ \\ Diabetes Research Centre, Madras, India and ${ }^{1}$ Royal Postgraduate Medical School, Hammersmith Hospital, London, UK
}

\begin{abstract}
Summary. Clinical and biochemical studies were carried out in 33 patients with diabetes secondary to chronic calcific, nonalcoholic pancreatitis (tropical pancreatic diabetes) and in 35 Type 2 (non-insulin-dependent) diabetic patients and 35 nondiabetic subjects. Despite lower body mass indices, only $25 \%$ of patients with tropical pancreatic diabetes had clinical evidence of malnutrition. There was no history of cassava ingestion. Mean serum cholesterol concentration was significantly lower in the tropical pancreatic diabetic patients $(p<0.01)$ in comparison with the Type 2 diabetic patients or non-diabetic subjects, due to a significantly decreased concentration of LDL cholesterol $(p<0.01)$ and VLDL cholesterol $(p<0.05)$. Basal and post-glucose stimulated concentrations of serum Cpeptide were highest in those pancreatic diabetic patients
\end{abstract}

( $n=11$ ) who responded to oral hypoglycaemic drugs, intermediate in the majority $(n=17)$, who were insulin dependent and ketosis resistant and negligible in a small sub-group $(n=5)$ who were ketosis prone. The occurrence of microangiopathy in pancreatic diabetic patients was common and similar to that in Type 2 diabetic patients. Thus, tropical pancreatic diabetes in South India appears to be heterogenous with respect to level of nutrition, severity of glucose intolerance, B-cell function, response to therapy and the occurrence of microvascular complications.

Key words: Tropical pancreatic diabetes, heterogeneity, ketosis-resistant, C-peptide, microangiopathy.
While classical Type 1 (insulin-dependent) diabetes and Type 2 (non-insulin-dependent) diabetes are two well characterized entities of the diabetic syndrome, there are certain types of diabetes which do not fit into either of these categories. In tropical countries, diabetes associated with malnutrition, such as $\mathbf{J}$-type diabetes $[1,2]$ and tropical pancreatic diabetes [3-6], have been described. Earlier studies have suggested the following characteristics of tropical pancreatic diabetes $[5,6]:(1)$ Patients belong to the lowest socio-economic strata of society and appear grossly emaciated with signs of severe protein-calorie malnutrition. (2) They have severe insulin-dependent diabetes and often require large doses of insulin for stabilization of the diabetes. However, they are resistant to ketosis on withdrawal of insulin even for several weeks. (3) A history of cassava ingestion is very common.

Recently, an explanation for the ketosis-resistant nature of tropical pancreatic diabetes has been put forward [7]. The present study demonstrates an interesting clinical and biochemical spectrum of tropical pancreatic diabetes as seen in the state of Tamilnadu (Madras) in South India.

\section{Subjects and methods}

Subjects studied were attending the M. V. Hospital for Diabetes, Madras, a large referral centre for diabetes in South India.

The following criteria were used for diagnosis of tropical pancreatic diabetes: (1) a history of recurrent abdominal pain from an early age; (2) the presence of pancreatic calculi seen on plain abdominal Xray and confirmed by ultrasonography; (3) the absence of alcoholism, gall-stones or hyperparathyroidism; and (4) diabetes. The study population consisted of 33 patients with tropical pancreatic diabetes seen consecutively during 1983 and 1984, who satisfied all the above criteria. There were 23 men and 10 women in the age group $16-47$ years. Their mean age was $32 \pm 1$ years and the mcan age at diagnosis of diabetes was $25 \pm 1$ years. Twenty-nine had no family history of diabetes, and in only three did a first degree relative have diabctes. Ten patients had evidence of steatorrhoea. A detailed medical and family history of diabetes was recorded. A specific enquiry about the ingestion of cassava (tapioca) was made in every case.

Thirty-fjve patients with Type 2 diabetes matched for duration of diabetes were also studied. Eighteen had a family history of diabetes. Three were hypertensive. The mean duration of hypertension was 4.5 years and blood pressure ranged between $150 / 100$ and $190 / 120 \mathrm{mmHg}$.

Thirty-five non-diabetic subjects matched for age and sex with the two groups of diabetic patients were also studied. None had a family history of diabetes. The clinical details of the study groups are summarized in Table 1. Informed consent was obtained from all subjects and approval of the study was obtained from the Hospital Ethical Committee.

\section{Study design}

All patients underwent a thorough clinical examination. Body mass index was calculated $\left(\mathrm{kg} / \mathrm{m}^{2}\right)$. Hypertension was defined as blood pressure $>140 / 95 \mathrm{mmHg}$. All patients had a resting ECG taken. Ischaemic heart disease was considered to be absent unless there was a clear history of angina pectoris or myocardial infarction or ischaemia, infarction or left bundle branch block was present in the ECG. All ECG's were reviewed by a cardiologist and they were assessed in accordance with the Minnesota code adapting the WHO study questionnaire for macrovascular disease [8]. Deep tendon jerks and vibration sense were tested and peripheral pulses in the feet were recorded clinically and by doppler ultrasound (Medasonics, Mountain View, 
USA). Neuropathy was defined as the absence of ankle jerks bilaterally or gross sensory disturbance in both feet. The criteria for peripheral vascular disease were those of the WHO Multinational Study of Vascular Complications [9]. Peripheral vascular disease was deemed to be present if there was a history of intermittent claudication or if one or more peripheral pulse (dorsalis pedis or posterior tibial) was absent. A plain X-ray examination of the abdomen and a PA view of the chest were taken. In patients with tropical pancreatic diabetes the presence of pancreatic calculi and fibrosis was confirmed by ultrasonography.

The fundi were examined by an ophthalmologist both by direct and indirect ophthalmoscopy. Diabetic retinopathy was classified as either background or proliferative according to the classification of Kohner et al. [10].

\section{Biochemical investigations}

A 75-g oral glucose tolerance test was carried out in all subjects. We used the recommendations of the WHO Expert Committee for the diagnosis of diabetes and classification into Type 2 diabetes [11]. The diagnosis of diabetes was accepted if either the fasting venous plasma glucose was $>8 \mathrm{mmol} / 1$ or the $2 \mathrm{~h}$ value was $>11 \mathrm{mmol} / 1$. Plasma glucose was estimated by the orthotoluidine method [12]. Glycosylated haemoglobin $\left(\mathrm{HbA}_{1}\right)$ was estimated by a colorimetric method [13].

Table 1. Clinical details of the subjects studied

\begin{tabular}{|c|c|c|c|}
\hline & $\begin{array}{l}\text { Patients with } \\
\text { tropical } \\
\text { pancreatic } \\
\text { diabetes }(n=33)\end{array}$ & $\begin{array}{l}\text { Type } 2 \\
\text { diabetic } \\
\text { patients } \\
(n=35)\end{array}$ & $\begin{array}{l}\text { Non-diabetic } \\
\text { subjects } \\
(n=35)\end{array}$ \\
\hline Male: female & $23: 10$ & $24: 11$ & $24: 11$ \\
\hline Age (years) & $\begin{array}{c}32 \pm 1 \\
(16-47)\end{array}$ & $\begin{array}{c}35 \pm 2 \\
(23-48)\end{array}$ & $\begin{array}{c}32 \pm 1 \\
(20-47)\end{array}$ \\
\hline Age at onset (years) & $25 \pm 1$ & $28 \pm 2$ & - \\
\hline $\begin{array}{l}\text { Duration of } \\
\text { diabetes (years) }\end{array}$ & $\begin{array}{l}7 \pm 1 \\
(1-15)\end{array}$ & $\begin{array}{l}7 \pm 1 \\
(2-15)\end{array}$ & - \\
\hline \multicolumn{4}{|l|}{$\begin{array}{l}\text { Body mass index } \\
\left(\mathrm{kg} / \mathrm{m}^{2}\right)\end{array}$} \\
\hline Men & $17.0 \pm 0.4$ & $23.5 \pm 4.6$ & $22.3 \pm 2.1$ \\
\hline Women & $18.8 \pm 1.2$ & $22.5 \pm 1.5$ & $21.2 \pm 1.5$ \\
\hline $\begin{array}{l}\text { Fasting plasma } \\
\text { glucose } \\
(\mathrm{mmol} / \mathrm{l})\end{array}$ & $13.0 \pm 0.7$ & $10.8 \pm 0.8$ & $6.4 \pm 0.4$ \\
\hline $\begin{array}{l}\text { Post-prandial } \\
\text { plasma glucose } \\
(\mathrm{mmol} / \mathrm{l})\end{array}$ & $21.3 \pm 0.7$ & $17.3 \pm 0.9$ & $8.3 \pm 0.5$ \\
\hline $\mathrm{HbA}_{1}(\%)^{\mathrm{b}}$ & $12.6 \pm 0.3$ & $11.7 \pm 0.3$ & $6.9 \pm 0.2$ \\
\hline
\end{tabular}

Values are expressed as mean \pm SEM with ranges in parentheses.

a Plasma glucose values for the diabetic subjects are before the control of diabetes; ${ }^{b}$ normal value for $\mathrm{HbA}_{1}: 5-8 \%$
Serum triglyceride [14], total serum cholesterol [15], HDL-cholesterol [16], and VLDL and LDL-cholesterols [17] were determined in the fasting state. Blood urea, serum creatinine [18] and creatinine clearance were determined in all the patients. Proteinuria was assessed by estimating the 24-h urinary protein excretion by the sulphosalicylic acid method [19]. Those with values $>500 \mathrm{mmol}$, in the absence of urinary tract infection or severe hypertension, were considered to have nephropathy. Renal insufficiency was defined as a serum creatinine $>133 \mu \mathrm{mol} / 1$.

Serum C-peptide levels were assayed by radioimmunoassay [20] using M1230 antiserum (Novo, Copenhagen, Denmark). The serum samples were extracted with equal volumes of $30 \%$ polyethylene glycol to remove insulin antibodies and proinsulin according to the procedure of Kuzuya et al. [21].

\section{Statistical analysis}

The data are expressed as mean \pm SEM and comparison between sets of data was made using the Student's t-test.

\section{Results}

The mean body mass index was lower in both men and women with tropical pancreatic diabetes when compared with age- and sex-matched Type 2 diabetic patients or non-diabetic subjects. While most of the tropical pancreatic diabetic patients were underweight (71\%), overt evidence of protein-calorie malnutrition was seen only in $25 \%$. Nine patients $(25 \%)$ were anaemic, the skin changes of malnutrition were seen in two $(6 \%)$ and one patient each had evidence of parotid gland enlargement, abdominal swelling and pedal oedema. Cyanotic hue of the lips was not seen in any patient. There was no history of cassava ingestion in any patient.

\section{Serum lipids}

Serum lipid concentrations in the three groups are shown in Table 2. The mean serum total cholesterol, LDL-cholesterol and VLDL-cholesterol concentrations were significantly lower in tropical pancreatic diabetic patients compared with Type 2 diabetic patients or nondiabetic subjects $(p<0.01)$. Women with tropical pancreatic diabetes also had lower levels of HDL-cholesterol $(p<0.01)$. Mean serum triglyceride levels were normal in all the tropical pancreatic diabetic patients.

Table 2. Serum lipid concentrations in patients with tropical pancreatic diabetes compared with Type 2 diabetic patients and non-diabetic subjects

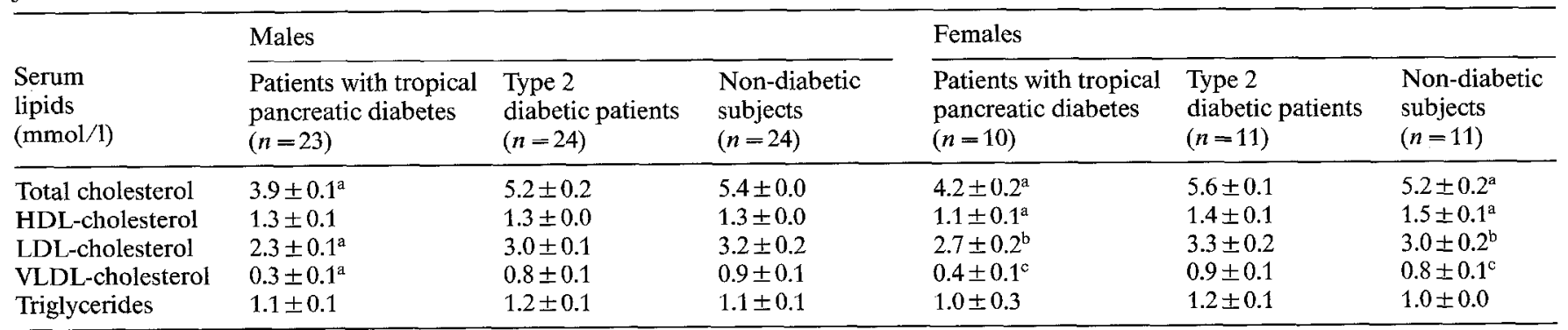

Results are expressed as mean \pm SEM. ${ }^{\mathrm{a}} p<0.01$ compared with non-diabetic subjects or Type 2 diabetic patients; ${ }^{\mathrm{b}} p<0.01$ compared with Type 2 diabetic patients; ${ }^{c} p<0.05$ compared with non-diabetic subjects or Type 2 diabetic patients 
Table 3. Basal and post-glucose peak levels of serum C-peptide levels in patients with tropical pancreatic diabetes

\begin{tabular}{llll}
\hline & $\begin{array}{l}\text { Duration } \\
\text { of diabetes } \\
\text { (years) }\end{array}$ & \multicolumn{2}{l}{ C-peptide (pmol/ml) } \\
\cline { 3 - 4 } & & $0.61 \pm 0.04$ & $1.53 \pm 0.13$ \\
\hline $\begin{array}{l}\text { Non-diabetic } \\
\text { subjects }(n=35)\end{array}$ & $7.0 \pm 0.9$ & $0.36 \pm 0.05$ & $0.98 \pm 0.18$ \\
$\begin{array}{l}\text { Type 2 diabetic } \\
\text { patients }(n=35)\end{array}$ & & & \\
$\begin{array}{l}\text { Tropical pancreatic } \\
\text { diabetic patients }\end{array}$ & & & \\
$\begin{array}{l}\text { Group } A \text { ( } n=5) \\
\text { (insulin-dependent and } \\
\text { ketosis-prone) }\end{array}$ & $9.8 \pm 4.1$ & $0.07 \pm 0.01$ & $0.09 \pm 0.04$ \\
$\begin{array}{l}\text { Group } B \text { ( } n=17) \\
\text { (insulin-dependent and }\end{array}$ & $5.9 \pm 0.9$ & $0.13 \pm 0.06$ & $0.23 \pm 0.05^{\mathrm{a}}$ \\
$\quad$ ketosis-resistant) & & & \\
$\begin{array}{c}\text { Group } C(n=11) \\
\text { (responding to oral } \\
\text { therapy) }\end{array}$ & $6.2 \pm 1.6$ & $0.17 \pm 0.04^{\mathrm{a}}$ & $0.48 \pm 0.16^{\mathrm{a}}$ \\
\hline
\end{tabular}

Values expressed as mean \pm SEM. ${ }^{a} p<0.05$ compared with group A

Table 4. Vascular complications in patients with tropical pancreatic diabetes and Type 2 diabetes

\begin{tabular}{|c|c|c|c|c|}
\hline \multirow[t]{3}{*}{ Diabetic complications } & \multicolumn{4}{|c|}{ Number with complications } \\
\hline & \multicolumn{2}{|c|}{$\begin{array}{l}\text { Tropical pan- } \\
\text { creatic diabetes } \\
(n=33)\end{array}$} & \multicolumn{2}{|c|}{$\begin{array}{l}\text { Type } 2 \text { diabetes } \\
(n=35)\end{array}$} \\
\hline & $n$ & $\%$ & $n$ & $\%$ \\
\hline Retinopathy $(n=28)$ & 11 & 39 & 15 & 43 \\
\hline Background & 9 & 32 & 11 & 31 \\
\hline Proliferative & 2 & 7 & 4 & 12 \\
\hline Nephropathy & 4 & 7 & 5 & 14 \\
\hline Renal insufficiency & 2 & 17 & 3 & 9 \\
\hline Peripheral neuropathy & 11 & 33 & 14 & 40 \\
\hline Ischaemic heart disease & 1 & 3 & 4 & 12 \\
\hline Peripheral vascular disease & 0 & 0 & 1 & 3 \\
\hline
\end{tabular}

\section{Serum C-peptide analysis}

The basal and glucose stimulated levels of serum $C$ peptide in tropical pancreatic diabetic patients, Type 2 diabetic patients and non-diabetic subjects are shown in Table 3. Tropical pancreatic diabetic patients could be classified into three groups based on their clinical characteristics.

Group $A$ : $(n=5)$ These patients were insulin-dependent and showed evidence of ketosis when insulin injections were stopped for periods even as short as 2-3 days. Basal and stimulated levels of C-peptide were lowest in this group.

Group $B:(n=17)$ This group consisted of the majority of the tropical pancreatic diabetic patients. They required insulin for the control of hyperglycaemia, but when the insulin injections were withdrawn even for several weeks, there was no evidence of ketosis. The Cpeptide concentrations were intermediate in this group (group B versus group A, $p<0.05$ ).
Group $C:(n=11)$ This group of patients responded to oral therapy and had the highest C-peptide levels (group $\mathrm{C}$ versus group $\mathrm{A}, p<0.05$ ).

\section{Prevalence of diabetic complications}

Microvascular and macrovascular complications in tropical pancreatic diabetic patients are shown in Table 4. Retinopathy was the most common, occurring in $39 \%$ of patients ( $32 \%$ had background; $7 \%$ had proliferative retinopathy). Nephropathy was present in $11 \%$ of patients; $31 \%$ had peripheral neuropathy. Only one patient $(3 \%)$ had ischaemic heart disease and none had peripheral vascular disease. The prevalence of all complications was only marginally lower than in the Type 2 diabetic patients.

\section{Discussion}

Most of the earlier literature on tropical pancreatic diabetes in southern India has been from the state of Kerala $[5,22,23]$ where cassava (tapioca) is consumed by poor people as a staple food instead of cereals; this has been proposed as the cause of this condition [24]. In Tamil Nadu, cassava is rarely consumed. We found no history of cassava ingestion in any patient with tropical pancreatic diabetes in the present series. However, the possibility of other unidentified toxins in foodstuffs cannot be ruled out.

Though the majority of patients with tropical pancreatic diabetes were lean, only $25 \%$ showed clinical signs of malnutrition. Nine were of ideal body weight and one was slightly overweight. This suggests that malnutrition, hitherto considered an important aetiological factor for tropical pancreatic diabetes might not be as important as was believed. Using routine X-ray examination of the abdomen, we were able to identify patients with possible tropical pancreatic diabetes.

Most cases of tropical pancreatic diabetes reported in the literature are insulin-dependent. We have previously reported two patients who responded to oral therapy [25]. In this study we found that among tropical pancreatic diabetic patients there is a sub-group who responded to oral hypoglycaemic therapy and they had the highest basal and post-load glucose-stimulated serum C-peptide levels. The insulin-dependent and ketosis-prone group had very low C-peptide levels, similar to those found in Type 1 diabetes. In agreement with our earlier report [7], we found that patients who were insulin-dependent but ketosis-resistant, had significantly higher C-peptide levels than patients with Type 1 diabetes. Thus, response to treatment in tropical pancreatic diabetic patients seems to depend on the C-peptide levels, which in turn, probably depend on the amount of viable islet cell mass. Pancreatic fibrosis, the characteristic pathology in this condition [24], appears to occur more slowly in some individuals. Thus, two tropical pancreatic diabetic patients at our centre only have impaired glucose tolerance and are treated with diet alone. 
Patients with tropical pancreatic diabetes have low serum cholesterol concentrations compared with Type 2 diabetic patients or non-diabetic subjects. This appears to be due to the low LDL-cholesterol level in men and low LDL- and HDL-cholesterol levels in women. The observation that young women with tropical pancreatic diabetes have significantly lower HDL-cholesterol levels is interesting because the opposite is true of young non-diabetic women and young women with Type 2 diabetes [27]. This may be a result of endocrine abnormalities which are frequently seen in female patients with tropical pancreatic diabetes [28].

There is very little data available on the vascular complications in tropical pancreatic diabetes although earlier reports have suggested that microangiopathy was extremely rare [29]. In this series, 39\% had retinopathy and 7\% had proliferative retinopathy. Nephropathy and renal insufficiency also occurred in these patients. These prevalence rates are only marginally lower than in the Type 2 diabetic patients. Thus, microvascular, in contrast to macrovascular, complications are not uncommon in tropical pancreatic diabetes. Admittedly, the numbers are small and large prospective studies are needed for more accurate figures on vascular complications in this condition.

To summarize, the present study shows certain peculiarities and clinical variations compared with earlier reports [5, 6, 22-24]. Protein-calorie malnutrition and cassava ingestion do not appear to be essential aetiological factors as believed previously. The extent of damage to the pancreatic B cells appears to be variable and the response to therapy is dependent on this. Microangiopathy, even in a severe form, does occur in tropical pancreatic diabetes. The clinical profile of tropical pancreatic diabetes appears to show heterogeneity even within South India.

Acknowledgements. The authors wish to thank the Novo Research Institute, Denmark, for supplying the C-peptide kits used in this study and Dr. D. Sreeram of the Dr. Henschke Memorial Research Foundation, Madras, for performing the ultrasonographic studies. Dr. Mohan was supported by the Rameshwardasji Birla Smarak Kosh.

\section{References}

1. Jones H (1955) Diabetes in Jamaica. Lancet 2: 891-897

2. Kar BC, Tripathi BB (1965) Observation on type J diabetes. J Assoc Physicians India 13: 181-187

3. Campbell GD, McNeill WG (1959) Diabetes in the tropics. $\mathrm{Br}$ Med J 2: 633-634

4. Zuidema PJ (1959) Cirrhosis and disseminated calcification of the pancreas in patients with malnutrition. Trop Geog Med 11:70-74

5. Geevarghese PJ (1968) Pancreatic diabetes. Popular Prakashan, Bombay, pp 110-115

6. Viswanathan M (1980) Pancreatic diabetes in India: an overview. In: Podolsky S, Viswanathan M (eds) Secondary diabetes: the spectrum of the diabetic syndromes. Raven Press, New York, pp $105-116$

7. Mohan V, Snehalatha C, Ramachandran A, Jayashree R, Viswanathan $M$ (1983) Pancreatic beta cell function in tropical pancretic diabetes. Metabolism 32: 1091-1092
8. Jarrett RJ, Keen H, Grabauskas V (1979) The WHO multinational study of vascular disease in diabetes. Diabetes Care 2:175-186

9. Keen H, Jarrett RJ (1979) The WHO multinational study of vascular disease in diabetes: macrovascular disease prevalence. Diabetes Care 2: 187-195

10. Kohner EM, McLeod D, Marshall J (1982) Diabetic eye disease In: Keen H, Jarrett RJ (eds) Complications of diabetes, 2nd edn. Edward Arnold, London, pp 19-108

11. WHO Expert Committee on Diabetes (1980) Technical Report Series No 646, Geneva

12. Hyvarinen A, Nikkila EA (1962) Specific determination of blood glucose with orthotoluidine. Clin Chim Acta 7:140-144

13. Eross J, Kreutzmann D, Jimenez M, Keen R, Rogers S, Cowell C, Vines R, Silink M (1984) Colorimetric measurement of glycosylated protein in whole blood, red blood cells, plasma and dried blood. Ann Clin Biochem 21: 519-522

14. Vanhandel E, Zilversmit DB (1957) Micromethod for determination of serum triglyceride. J Lab Clin Med 50: 152-156

15. Zak B, Dickermann RC, White EC, Barnett H, Chernoy PJ (1954) Rapid estimation of free and total cholesterol. Am J Clin Pathol 24: $1307-1315$

16. Burstein M, Scholnick HR, Morfin R (1970) Rapid method for isolation of lipoproteins from human serum by precipitation with polyanions. J Lipid Res 11: 583-595

17. Ononogha IC, Lewis B (1976) Lipoprotein fractionation by a precipitation method, a simple quantitative procedure. Clin Chim Acta 71: 397-402

18. Varley H, Gowenlock AH, Bell M (1980) Practical clinical biochemistry. Heinmann, London, pp 479-480

19. Varley H, Gowenlock AH, Bell M (1980) Practical clinical biochemistry. Heinmann, London, pp 600-601

20. Heding LG (1975) Radioimmunological determination of human C-peptide in serum. Diabetologia 11: 541-548

21. Kuzuya H, Blix PM, Horwitz DL (1977) Determination of free and total insulin and $\mathrm{C}$-peptide in insulin treated diabetics. Diabetes $26: 22-29$

22. Geevarghese PJ, Pillay VK, Joseph MP, Pitchumoni CS (1973) The diagnosis of pancreatic diabetes mellitus. J Assoc Physicians India 10: 173-180

23. Pai KN, Ramachandran M (1974) Diabetes mellitus in endemic pancreatic syndrome of Kerala. In: Kumar V (ed) Disorders of carbohydrate metabolism. Arnold Heinnemann, New Delhi, pp 139-150

24. McMillan DE, Geevarghese (1979) Dietary cyanide and tropical malnutrition diabetes. Diabetes Care 2: 202-208

25. Ramachandran A, Mohan V, Snehalata C, Viswanathan M (1977) Diabetics with pancreatic calcification behaving as maturity onset diabetes. J Diab Assoc India 17: 91-94

26. Nagalotimath SJ (1980) Pancreatic pathology in pancreatic calcification with diabetes. In: Podolsky S, Viswanathan M (eds) Secondary diabetes: the spectrum of the diabetic syndromes. Raven Press, New York, pp 117-145

27. Aleyssaine H, Gardiner RJ, Tonks DB, Koch P (1980) Glycosylated hemoglobin in diabetes mellitus: correlation with fasting plasma glucose, serum lipids and glycosuria. Diabetes Care 3: 509-514

28. Ramachandran M, Pai KN (1977) Pancreatic diabetes: clinical features and management. In: Rao BM (ed) Diabetes mellitus. Arnold Heinnemann, New Delhi, pp 239-246

29. West KM (1978) Epidemiology of diabetes and its vascular lesions. Elsevier, New York, pp 324-331

Received: 6 August 1984

and in revised form: 22 February 1985

Dr. V. Mohan

5 Main Road

Royapuram

Madras 600013

India 